\title{
PENGARUH KOMBINASI PIJAT BAYI DENGAN MUSIK KLASIK MOZART TERHADAP BERAT BADAN DAN KUALITAS TIDUR BAYI USIA 3-6 BULAN
}

\author{
Sendi Mahareni ${ }^{1)}$, Farida Sukowati $^{2)}$,Elisa Ulfiana ${ }^{3)}$ \\ E-mail :smahareni@gmail.com
}

\begin{abstract}
ABSTRAK
Di Puskesmas Gubug II terdapat 43 dari 430 (10 \%) bayi dalam kategori bawah garis merah dan 5 dari $19(0,7 \%)$ bayi mengalami gangguan tidur. Penelitian ini bertujuan untuk mengetahui pengaruh kombinasi pijat bayi dengan musik klasik mozart terhadap berat badan dan kualitas tidur bayi.

Desain penelitian menggunakan quasy eksperimen dengan pre post control group design. Jumlah responden sebanyak 38 bayi dengan 19 bayi kelompok perlakuan dan 19 bayi kelompok kontrol.

Berat badan diukur dengan timbangan bayi digital dan kualitas tidur menggunakan kuesioner Brief Infant Screening Questionnaire (BISQ). Penelitian dilakukan 2x dalam 4 minggu setiap sore hari.Hasil penetilian ini didapatkan bahwa terdapat peningkatan yang lebih baik berkaitan dengan berat badan yaitu sebesar 694,58 gram dan peningkatan kualitas tidur sebesar 4 poin pada kelompok eksperimen setelah dilakukan intervensi.

Terdapat pengaruh antara kombinasi pijat bayi dengan musik klasik mozart terhadap berat badan dengan $p$ value $0,001<0,05$ dan kualitas tidur dengan $p$ value $0,001<0,05$ pada bayi usia 3-6 bulan.

Di harapkan orang tua dapat memilih kombinasi pijat bayi dengan musik klasik mozart sebagai alternatif untuk meningkatkan berat badan dan kualitas tidur bayi. Untuk Institusi diharapkan lebih mengembangkan kombinasi pijat bayi dan untuk peneliti selanjutnya agar bisa mengembangkan metode penelitian yang lain.

Kata kunci : berat badan,kualitas tidur, musik klasik Mozart, pijat bayi

1), 2), 3), Civitas Akademika Jurusan Kebidanan; Poltekkes Kemenkes Semarang

AKB Indonesia mengalami penurunan dari tahun ke tahun dibuktikan dengan jumlah AKB Indonesia pada tahun 2015 Sebesar 22,23 per 1000 lebih rendah dari tahun 2014 yaitu sebesar 32 per 1000 kelahiran hidup (Kemenkes, 2015).AKB di Provinsi Jawa Tengah mengalami penurunan dari 2 tahun terakhir. Hal ini di buktikan dengan jumlah AKB Provinsi Jawa Tengah tahun 2015 sebesar 10 per 1000 kelahiran hidup yang lebih rendah dari tahun 2014 yaitu 10,08 per

1000 kelahiran hidup (Dinas Kesehatan Provinsi, 2015). Kabupaten Grobogan mengalami penurunan jumlah AKB yaitu 10,87 per 1000 kelahiran hidup pada tahun 2014 menjadi 10,38 per 1000 kelahiran hidup pada tahun 2015. Menurut Kemenkes (2010) salah satu penyebab AKB adalah status gizi. Puskesmas Gubug II, salah satu Puskesmas di wilayah Kabupaten Grobogan mengalami peningkatan angka kurang gizi dari $0,6 \%$ pada tahun 2014 menjadi 0,9
\end{abstract}


\% pada tahun 2015. Di Puskesmas Gubug II terdapat 430 bayi dengan prevalensi $10 \%$ bayi mengalami Berat Badan di Bawah Garis Merah (BGM). Program yang telah di jalankan oleh Dinas Kesehatan Kabupaten Grobogan untuk menangani bayi BGM adalah dengan melakukan peningkatan nutrisi.

Upaya yang dilakukan antara dengan melakukan promosi kesehatan tentang gizi bayi kepada masyarakat serta di berikan Pemberian Makanan Tambahan (PMT) untuk bayi kurang gizi diatas usia 6 bulan (Dinas Kesehatan Kabupaten Grobogan, 2015).

Salah satu faktor yang mempengaruhi pertumbuhan adalah stimulasi. Bebe-rapa pedoman untuk stimulasi bayi di antaranya stimulasi penglihatan, sti-mulasi pendengaran, stimulasi taktil atau perabaan, serta koordinasi visual dan gerak (Fida dan Maya, 2012).

Menurut Roesli (2008) bayi yang dipijat mengalami peningkatan tonus nervus vagus (saraf otak ke 10) yang membuat kadar enzim penyerapan gastrin dan insulin meningkat sehingga penyerapan sari makanan lebih baik yang akan meningkatkan pertumbuhan. Pijat bayi akan meningkatkan kadar sekresi serotonin yang akan meningkatkan kualitas tidur bayi (Roesli,2008).

Serotonin akan berubah menjadi melatonin yang mempunyai peran dalam tidur dan membuat tidur lebih lama dan lelap pada saat malam (Lilik dan Diah, 2014). Selain dengan pijat bayi, pemberian musik juga dapat meningkatkan kualitas tidur bayi.

Berdasarkan penelitian yang dilakukan oleh Wahyuningsih dan $\mathrm{Ni}$ Luh Putu (2014) menunjukkan adanya peningkatan berat badan dimungkinkan karena terapi musik klasik dapat memberikan perasaan tenang kepada bayi sehingga bayi lebih banyak tidur.
Peneliti melakukan studi pendahuluan mengenai kualitas tidur bayi menggunakan kuesioner Brief Infant Sleep Questionnaire (BISQ) yang merupakan salah satu perangkat yang digunakan untuk mengukur kualitas tidur anak di bawah usia 3 tahun (Sari Pediatri,2006). Hasil dari studi yang dilakukan terdapat 5 dari 19 bayi yang mengalami masalah tidur.

Berdasarkan data dan teori yang di kemukakan diatas maka kombinasi dari 2 atau lebih dari masing-masing stimulasi akan berdampak positif pada berat badan dan kualitas tidur bayi. Selain itu, kombinasi pijat bayi dan musik klasik mozart memiliki banyak manfaat untuk bayi dan mudah di aplikasikan oleh tenaga kesehatan maupun orang tua.

Berdasarkan uraian masalah dan studi pendahuluan yang dilakukan peneliti ingin melakukan penelitian dengan judul “ Pengaruh Kombinasi Pijat Bayi dengan Musik Klasik Mozart Terhadap Berat Badan dan Kualitas Tidur Bayi Usia 3-6 bulan di Wilayah Kerja Puskesmas Gubug II ".

\section{METODE}

Metode penelitian yang digunakan adalah quasy eksperimental dengan rancangan pretest-posttest with control group. Penelitian dilakukan di wilayah kerja Puskesmas Gubug II Kabupaten Grobogan pada bulan April - Mei 2017. Sampel dalam penelitian ini adalah bayi dengan suia 3-6 bulan yang hanya diberikan ASI Eksklusif.

Pengambilan sampel menggunakan total sampling yang didapatkan sebanyak 38 bayi dimana di bagi menjadi 2 kelompok yaitu kelompok eksperimen dan kelompok kontrol. Kelompok eksperimen terdiri dari 19 bayi yang diberikan intervensi kom- 
binasi pijat bayi dengan musik klasik mozart yang dilakukan 2 kali dalam 4 minggu pada sore hari oleh bidan yang telah memiliki sertiffikat pijat bayi. Sedangkan kelompok kontrol terdiri dari 19 bayi yang diberikan ASI Eksklusif.

Pengukuran berat badan menggunakan timbangan bayi digital dengan ketelitian $0,001 \mathrm{~kg}$ yang telah dilakukan uji kalibrasi. Sedangkan untuk pengukuran kualitas tidur bayi menggunakan Brief Infant Screening Questionnaire (BISQ) yang memiliki 5 pertanyaan terstruktur dengan penilaian 1-5 menunjukkan masalah berat, $6-10$ menunjukkan masalah ringan sedangkan 11-15 menunjukkan tidak ada masalah dalam tidur.Telah dilakukan uji validitas dan reliabilitas terhadap kuesioner BISQ.

\section{HASIL DAN PEMBAHASAN}

Tabel 1.

Hasil Analisis Univariat Berat Badan dan Kualitas Tidur.

\begin{tabular}{|c|c|c|c|}
\hline Data & Mean & Min & Max \\
\hline \multicolumn{4}{|l|}{$\begin{array}{l}\text { Kelompok } \\
\text { eksperimen }\end{array}$} \\
\hline Berat badan sebelum & $* 6215$ & $* 5312$ & $* 7084$ \\
\hline Berat badan setelah & $* 6909,58$ & $* 5910$ & $* 7703$ \\
\hline $\begin{array}{l}\text { Skor Kualitas tidur } \\
\text { sebelum }\end{array}$ & 8 & 6 & 10 \\
\hline $\begin{array}{l}\text { Skor Kualitas tidur } \\
\text { setelah }\end{array}$ & 12,37 & 10 & 14 \\
\hline \multicolumn{4}{|l|}{ Kelompok kontrol } \\
\hline Berat badan sebelum & $* 6179,37$ & $* 5462$ & $* 6823$ \\
\hline Berat badan setelah & $* 6660,89$ & $* 5945$ & $* 7357$ \\
\hline $\begin{array}{l}\text { Skor Kualitas tidur } \\
\text { sebelum }\end{array}$ & 8,05 & 6 & 11 \\
\hline $\begin{array}{l}\text { Skor Kualitas tidur } \\
\text { setelah }\end{array}$ & 8,37 & 6 & 11 \\
\hline
\end{tabular}

* berat badan dalam satuan gram

Berdasarkan tabel 1 didapatkan hasil bahwa rata - rata berat badan pada kelompok eksperimen sebelum di lakukan intervensi pemberian kombinasi pijat bayi dengan musik klasik mozart sebesar 6215 dengan berat badan terkecil 5312 gram dan terbesar adalah 7084 gram.

Sedangkan setelah dilakukan intervensi didapatkan rata - rata berat badan bayi sebesar 6909,58 gram dengan berta badan terkecil 5910 gram dan terbesar adalah 7703 gram. Ratarata kualitas tidur pada kelompok eksperimen sebelum dilakukan intervensi adalah 8 poin (tidur dengan masalah ringan) dengan nilai terkecil 6 (tidur dengan masalah ringan) dan nilai terbesar 10 (tidur dengan masalah ringan). Sedangkan setelah dilakukan intervensi didapatkan rata - rata kualitas tidur bayi adalah 12 poin (tidur dengan masalah ringan) dengan nilai terkecil 10 (tidur dengan masalah ringan) dan nilai terbesar 14 (tidak ada masalah tidur).

Pada kelompok kontrol didapatkan rata - rata berat badan sebelum 4 minggu di lakukan pengukuran sebesar 6179,37 gram dengan berat badan terkecil 5462 gram dan terbesar adalah 6823 gram. Setelah 4 minggu di didapatkan hasil pengukuran ratarata berat badan bayi sebesar 6660,89 gram dengan berta badan terkecil 5945 gram dan terbesar adalah 7357 gram.

Rata - rata kualitas tidur pada kelompok kontrol sebelum 4 minggu pengukuran adalah 8 poin (tidur dengan masalah ringan) dengan nilai terkecil 6 (tidur dengan masalah ringan) dan nilai terbesar 11 (tidur dengan masalah ringan). Tidak ada peningkatan rata - rata kualitas tidur setelah 4 minggu pada kelompok kontrol.

Berdasarkan uraian diatas, maka telah terjadi peningkatan berat badan pada kelompok eksperimen dengan pemberian kombinasi pijat bayi dengan musik klasik mozart 2 kali dalam 4 
minggu dan pada kelompok kontrol yang hanya diberikan ASI Eksklusif. Selain itu, terjadi peningkatan skor kualitas tidur pada kelompok ekperimen. Sedangkan pada kelompok kontrol tidak terjadi peningkatan skor kualitas tidur.

Tabel 2.

Pengaruh Kombinasi Pijat Bayi dengan Musik Klasik Mozart Terhadap Berat Badan dan Kualitas Tidur Bayi

\begin{tabular}{llc}
\hline Variabel & $\begin{array}{l}\text { Selisih } \\
\text { Mean }\end{array}$ & P value \\
\hline $\begin{array}{l}\text { Kelompok Eksperimen } \\
\text { Berat badan sebelum dan }\end{array}$ & $* 694,58$ & 0,001 \\
setelah diberikan kombinasi \\
musik klasik mozart dengan \\
pijat bayi
\end{tabular}

Berdasarkan tabel 2 didapatkan hasil bahwa terdapat pengaruh yang signifikan antara berat badan bayi sebelum dan setelah dilakukan kombinasi pijat bayi dengan musik klasik mozart ( $\mathrm{p}$ value : 0,001<0,05 sehingga Ha diterima). Pada kelompok kontrol di dapatkan pula pengaruh yang signifikan antara berat badan bayi sebelum dan setelah 4 minggu pengukuran $(\mathrm{p}$ value : $0,001<0,05$ sehingga Ha diterima).

Pada penelitian ini didapatkan bahwa peningkatan rata - rata berat badan bayi pada kelompok eksperimen sebesar 694,58 gram sedangkan pada kelompok kontrol sebesar 481,52 gram. Hal ini berarti peningkatan rata - rata berat badan pada kelompok eksperimen yang diberikan kombinasi pijat bayi dengan musik klasik mozart lebih banyak jika dibandingkan dengan kelompok kontrol yang hanya di berikan ASI Eksklusif saja.

Menurut teori yang disampaikan oleh Roesli (2008) bahwa pijatan pada bayi akan meningkatkan pertumbuhan bayi. Saat dilakukan rangsangan taktil maka akan terjadi peningkatan enzim OCD (ornithine decarboxylase) yang merupakan suatu enzim yang menjadi petunjuk bagi pertumbuhan sel dan jaringan .

Pengurangan stimulasi taktil akan meningkatkan pengeluaran suatu neurochemical beta-endorphine, yang akan mengurangi pembentukan hormon pertumbuhan karena menurunnya jumlah dan aktivitas ODC jaringan. Selain itu, pijat bayi dapat meningkatkan penyerapan makanan dikarenakan bayi yang dipijat akan mengalami peningkatan tonus nervus vagus (saraf otak ke 10) yang akan menyebabkan peningkatan kadar enzim penyerapan gastrin dan insulin (Roesli, 2008). Dengan demikian , penyerapan makanan akan lebih baik dan akan menimbulkan peningkatan berat badan pada bayi setelah bayi di pijat.

Adanya pengaruh pijat terhadap pertumbuhan di buktikan dengan penelitian yang dilakukan oleh Sofiani (2011) menunjukkan setelah dilakukan pijat bayi teratur setiap 2 kali dalam 1 minggu selama 5 minggu oleh orang tua masing-masing bayi didapatkan hasil bahwa sebagian besar bayi mengalami peningkatan berat badan sebesar lebih dari sama dengan $1000 \mathrm{gr}$ yang dilakukan pada 11 bayi.

Menurut Natalia (2000) dalam penelitian Wahyuningsih dan Eka (2014) pengaruh musik gamelan terhadap emosi bayi baru lahir menunjukkan 
bahwa terdapat perbedaan berat badan dan pola tidur yang bermakna antara kelompok kontrol dan kelompok perlakuan. Pada penelitiannya didapatkan hasil bayi yang di putarkan musik gamelan memiliki peningkatan berat badan rata-rata 200 gram selama 2 minggu.

Hal ini sesuai dengan teori Menurut Lubetzky dalam Hariarti Suni (2010), musik yang didengarkan akan merangsang neuron untuk menghantarkan impuls melalui neuroendokrin. Neuroendokrin akan meningkatkan kinerja dehidroepiandosterone (DHEA) yang akan menyebabkan peningkatan hormon glukokortikoid yaitu hormon yang berperan dalam metabolisme nutrisi. Dengan adanya peningkatan nutrisi maka akan meningkatkan pertumbuhan bayi.

Pada penelitian ini dilakukan 2 stimulasi sekaligus yaitu kombinasi antara pijat bayi dengan musik klasik mozart yang masing- masing stimulasi terbukti dapat meningkatkan berat badan bayi sesuai dengan teori dan penelitian yang telah dijelaskan diatas. Sehingga saat diberikan kombinasi 2 stimulasi maka akan mendapatkan kenaikan berat badan bayi yang signifikan yaitu 694,58 gram pada kelompok perlakuan dan 481,53 gram pada kelompok kontrol.

Berdasarkan tabel 2 didapatkan hasil bahwa terdapat pengaruh yang signifikan antara skor kualitas tidur bayi sebelum dan setelah dilakukan kombinasi pijat bayi dengan musik klasik mozart ( $\mathrm{p}$ value : $0,001<0,05$ sehingga $\mathrm{Ha}$ diterima). Tetapi pada kelompok kontrol tidak didapatkan pengaruh yang signifikan antara skor kualitas tidur pada sebelum dan setelah 4 minggu pengukuran ( $\mathrm{p}$ value : $0,083>0,05$ sehingga Ha ditolak).
Pada penelitian ini didapatkan bahwa peningkatan rata - rata skor kualitas tidur bayi pada kelompok eksperimen sebesar 4 poin sedangkan pada kelompok kontrol sebesar 1 poin. Hal ini berarti peningkatan rata - rata skor kualitas tidur bayi pada kelompok eksperimen yang diberikan kombinasi pijat bayi dengan musik klasik mozart lebih banyak jika dibandingkan dengan kelompok kontrol yang hanya di berikan ASI Eksklusif saja.

Hal ini sesuai dengan teori bahwa pijat bayi akan meningkatkan kadar sekresi serotonin yang akan meningkatkan kualitas tidur bayi (Roesli,2008). Serotonin yang disintesis dari asam amino tripthophan. Serotonin akan di ubah menjadi 5 hidroksitripthophan (SHTP) kemudian menjadi $\mathrm{N}$ - asetil serotonin yang pada akhirnya berubah menjadi melatonin. Melatonin mempunyai peran dalam tidur dan membuat tidur lebih lama dan lelap pada saat malam (Lilik dan Diah, 2014).

Adanya pengaruh pijat bayi dengan peningkatan tidur bayi telah dibuktikan dengan penelitian oleh Lilik dan Diah (2014) yang menunjukkan bahwa kuantitas tidur bayi usia 3-6 bulan sesudah dilakukan pemijatan lebih tinggi (rerata 13,77 jam/hari) daripada sebelum pemijatan (rerata 12,42 jam/hari) dengan rerata peningkatan sebesar 1,29 jam/hari. Sehingga terdapat pengaruh pijat bayi terhadap kuantitas tidur bayi usia 3-6 bulan di Desa Munungrejo Kecamatan Ngimbang Kabupaten Lamongan.

Menurut Djohan (2006) Terapi musik berdampak positif untuk mengatasi stres karena dapat mengaktifkan sel-sel pada sistem limbik dan saraf otonom pasien, sehingga kekebalan tubuh meningkat dan 
merangsang pengeluaran endorphin dan serotonin.

Serotonin merupakan zat kimia yang mentransmisikan impuls saraf di seluruh ruangantara sel-sel saraf atau neuron dan memiliki peran dalam mencegah kecemasan, muntah, dan migrain. Perubahan tingkat serotonin dapat membuat suasana tenang, rileks. Sehingga dapat me-ningkatkan kualitas tidur.

Berdasarkan penelitian yang dilakukan oleh Wahyuningsih dan $\mathrm{Ni}$ Luh Putu (2014) menunjukkan adanya peningkatan berat badan dimungkinkan karena terapi musik klasik dapat memberikan perasaan tenang kepada bayi sehingga bayi lebih banyak tidur. Pemberian terapi musik merupakan salah satu stimulasi audio menggunakan musik dimana tujuannya adalah untuk meningkatkan atau memperbaiki pertumbuhan, emosi, kognitif, dan sosial bagi individu dari berbagai kalangan usia (Mahanani, 2013 dalam penelitian Cahyani,2015).

Pada penelitian ini dilakukan 2 stimulasi sekaligus yaitu kombinasi antara pijat bayi dengan musik klasik mozart yang masing- maisng stimulasi terbukti dapat meningkatkan kualitas tidur bayi sesuai dengan teori dan penelitian yang telah dijelaskan diatas. Sehingga saat diberikan kombinasi 2 stimulasi maka akan mendapatkan kenaikan kualitas tidur bayi 4 poin dari masalah tidur ringan menjadi tidak ada masalah dalam tidur. Dan pada kelompok kontrol hanya 0,23 poin yang menunjukkan angka tetap jenis kualitas tidur yaitu dengan masalah ringan.

\section{SIMPULAN DAN SARAN}

Rata-rata berat badan sebelum diberikan kombinasi pijat bayi dengan musik klasik mozart pada kelompok perlakuan adalah sebesar 6215 gram dan pada kelompok kontrol sebesar 6179,37 gram. Skor kualitas tidur ratarata sebelum pada kelompok eksperimen sebesar 8 dan pada kelompok kontrol adalah 8 sehingga tidak ada selisih skor kualitas tidur sebelum pada kelompok eksperimen dan kontrol.

Rata-rata berat badan setelah diberikan kombinasi pijat bayi dengan musik klasik mozart pada kelompok eksperimen adalah sebesar 6909,58 gram dan pada kelompok kontrol sebesar 6660,89 gram. Skor kualitas tidur rata- rata setelah pada kelompok eksperimen sebesar 12 (tidak ada masalah tidur) dan pada kelompok kontrol adalah 8 (masalah tidur ringan).

Berdasarkan uji statistik yang dilakukan, didapatkan hasil jika ada pengaruh antara kombinasi pijat bayi dengan musik klasik mozart terhadap berat badan dan kualitas tidur bayi. Terdapat kenaikan berat badan rata-rata pada kelompok eksperimen setelah diberikan kombinasi pijat bayi adalah sebesar 694,58 gram dan kenaikan kualitas tidur 4 poin (dari tidur dengan masalah ringan menjadi tidak ada masalah dalam tidur).

Berdasarkan pada kesimpulan hasil penelitian dapat diberikan saransaran diantaranya untuk orang tuadiharapkan orang tua untuk memilih kombinasi pijat bayi dengan musik klasik mozart sebagai alternatif lain untuk meningkatkan berat badan dan kualitas tidur bayi.

Untuk institusi Pendidikan diharapkan untuk memberikan pelatihan pijat bayi dengan berbagai kombinasi misalnya dengan musik klasik mozart atau dengan kombinasi yang lain.

Untuk peneliti selanjutnya diharapkan untuk peneliti selanjutnya 
dapat mengembangkan penelitian ini dengan menambah jumlah enumerator sehingga waktu yang diberikan untuk pelaksanaan kombinasi pijat bayi dengan musik klasik mozart dapat sama dengan responden yang lain.

\section{DAFTAR PUSTAKA.}

Djohan. (2006). Terapi Musik, Teori, dan Aplikasi. Yogyakarta: Galang Press.

Fida \& Maya. 2012. Pengantar Ilmu Kesehatan Anak. Jogjakarta: DMedika.

Hoelman, Mickael B. 2015. Pan-duan SDGs Untuk Pemerintah Daerah (Kota dan Kabupaten) dan Pemangku Kepentingan Daerah. Jakarta: Infid.

Kemenkes RI. 2014. Profil Kese-hatan Indonesia tahun 2014. Jakarta : Kemenkes RI.

Kemenkes RI. 2015. Profil Kesehatan Indonesia tahun 2015. Jakarta : Kemenkes RI.

Kementrian Kesehatan RI. 2012. Pedoman pelaksanaan stimulasi, deteksi dan intervensi dini tumbuh kembang anak ditingkat pelayanan kesehatan dasar. Jakarta: Departemen kesehatan, direktorat Jenderal pembi-naan kesehatan masyarakat.

Mahanani. A. (2013). Durasi Pemberian Musik Klasik Mozart Terhadap Tingkat Kecemasan Pada Anak. Purwokerto: Fakultas Kedok-teran dan Ilmu Kesehatan Keperawatan.
Mardiana, Lilik ; Mardini, Diah Eko. 2014. Pengaruh Pijat Bayi Terhadap Kuantitas Tidur Bayi Usia 3 - 6 Bulan di Desa Munungrejo Kecamatan Ngimbang Kabupaten Lamongan. Jurnal.

Maryunani, Anik. 2010. Ilmu Kesehatan Anak dalam Kebidanan. Jakarta: CV. Trans Info.

Minarti, Ni Made Aries ; Utami, Kadek Cahya. 2012. Pengaruh Pijat Bayi Terhadap Kualitas Tidur Bayi Usia 3-6 Bulan Di Wilayah Kerja Puskesmas II Denpasar Timur.

Prof. Dr. Sugiyono. 2011. Statis-tika untuk Penelitian. Bandung: Alfabeta.

Roesli, Utami. 2001. Pedoman Pijat Bayi (Edisi Revisi). Jakatra : PT. Trubus Agriwidya.

Sofiani, Ani. 2011. Perbedaan Kenaikan Berat Badan Antara Bayi Umur 0 - 6 Bulan yang Di pijat Bayi dan yang Tidak Dipijat Bayi di BPS Yohana Kota Semarang. Karya Tulis Ilmiah: Poltekkes Semarang.

Wahyuningsri ; Eka, Ni Luh Putu. 2014. Pemberian Terapi Musik Klasik Terhadap Reflek Hisap Dan Berat Badan Bayi Prematur. Jurnal Keperawatan : Poltekkes Kemenkes Malang. 